\title{
Bats (Mammalia: Chiroptera) in native and reforested areas in Rancho Alegre, Paraná, Brazil
}

\author{
Patrícia Helena Gallo ${ }^{1,3}$, Nelio Roberto dos Reis ${ }^{1,2}$, Fabio Rodrigo Andrade ${ }^{1}$ \\ \& Inaê Guion de Almeida ${ }^{1}$ \\ 1. Laboratory of Mammal Ecology, Department of Animal and Vegetal Biology, State University Londrina, 6001, 86051- \\ 970, Londrina, Paraná State, Brazil;patygallohc@yahoo.com.br \\ 2. Department of Animal and Vegetal Biology, State University Londrina, 6001, 86051-970, Londrina, Paraná \\ State,Brazil; nrreis@uel.br \\ 3. Pós-graduation in Ecologia de Ambientes Aquáticos Continentais - PEA, State University Maringá, 87020-900, \\ Maringá, Paraná State, Brazil.
}

Received 31-VIII-2009. Corrected 23-IV-2010. Accepted 25-V-2010.

\begin{abstract}
Generally, natural environments have been transformed into small forest remnants, with the consequent habitat loss and species extinction. The North Paraná State is not an exception, since only 2 to $4 \%$ of the original ecosystem occurs in small fragments of Stational Semidecidual Forest. We studied the species richness and abundance of bats in two forest fragments from the Fazenda Congonhas, in Rancho Alegre city, Paraná State, Brazil. Four samplings were undertaken in a legally protected native area (107.8ha) and in a reforested area (11.8ha) between April 2007 and March 2008. Samplings began at nightfall and lasted six hours, during two consecutive nights in each location. The individuals were captured using eight mist nets, with the same capture effort in both environments. A total of 397 individuals, 14 species and 10 genera were captured in the native area; while in the reforested area, 105 individuals, six species and four genera. Artibeus lituratus was the most common species in both fragments $(\mathrm{n}=328,65.3 \%)$, followed by Artibeus fimbriatus $(\mathrm{n}=44,8.8 \%)$ and Artibeus jamaicensis $(\mathrm{n}=30,6.0 \%)$. Other species including Platyrrhinus lineatus, Carollia perspicillata, Sturnira lilium, Chrotopterus auritus, Desmodus rotundus, Michronycteris megalotis, Phyllostomus hastatus, Phyllostomus discolor, Myoti levis, Myotis nigricans and Lasiurus blossevillii, accounted for $19.9 \%$ of the captures. The native area presented higher values of species richness $(S=14)$ and diversity $\left(H^{\prime}=1.4802\right)$ in comparison to the reforested area $\left(S=6, H^{\prime}=0.57015\right)$. The t-test evidenced a significant difference between diversity among the sites $(\mathrm{t}=7.1075)$. Chao 1 index indicated that the sampling effort recorded approximately $78 \%$ from the total species richness for the native area and $75 \%$ for the reforested area. Therefore, the preservation of the forest fragment is essential since it provides habitat for a diverse community of bats. Forest management and reforestation actions may prevent drastic changes in the microclimate of neighboring areas within the forest fragment, and could allow the occupation of available niches in the area, by opportunistic and generalist species. Rev. Biol. Trop. 58 (4): 1311-1322. Epub 2010 December 01.
\end{abstract}

Key words: chiropterans, forest fragments, diversity, conservation, Atlantic forest.

Several forests have been reduced to small remnants isolated from the others (Pires et al. 2006). The loss of habitat is one of the most common causes of species extinction (Hero \& Ridgway 2006), and may cause the extinction of some species with restricted distributions and impair other mammal species to maintain genetically viable populations within forest fragments (Marini-Filho \& Martins 2000, Pires et al. 2006).

Human activities represent a threat to habitats and species. This situation can be observed in the Northern region of Paraná State, where the agriculture and cattle-breeding are highly intensive due to the fertile soil. Approximately 2 to $4 \%$ of this region represents primary forest, 
which occurs in small remnant fragments of stational semidecidual forest. These fragments constitute islands of forest surrounded by areas of intensive agriculture and grazing (Torezan 2002, Reis et al. 2006a).

Some of the forest remnants in the region of Londrina County (Northern region of the Paraná State), such as the Mata dos Godoy State Park (680ha) and Arthur Thomas Municipal Park (85.47ha), have been transformed into preservation areas. Other cities from the Paraná State also present protected areas, such as Irati Floresta Nacional (3.5ha) in the cities of Fernandes Pinheiro and Teixeira Soares, and the State Park Mata São Francisco, with 832.57ha, in the cities of Cornélio Procópio and Santa Mariana. Private areas have also been transformed into preservation areas, such as the Klabin Biological Reserve Forest (11.196ha) in the city of Telêmaco Borba (Reis et al. 2000). However, most forest remnants are unprotected even though they are the last biodiversity repositories in the region.

Within the context of the destruction and reduction of the forests, the original habitat can be limited to the center of the remnant, or it may totally disappear in small remnants. The micro-environment of the forest edge is different from that found in the interior of the fragment, in function of the increase in the temperature, penetration of sun radiation, decrease in humidity and direct exposure to winds (Murcia 1995). These effects can modify the diversity and abundance of the fauna, which occurs more quickly in small fragments than in larger ones (Cosson et al. 1999).

Restoration of ecosystems, such as reforestation, allows the beginning or the continuity of the succession process (Cusack \& Montagnini 2004). When the existence of a minimal forest structure is assured, the colonization by new species and the development of the succession depends on the process of seed dispersal from neighboring sources, especially by biotic agents, such as birds and bats (Holl et al. 2000). Nevertheless, the occurrence of seed dispersal animals in restoration sites depends on the vegetation structure and resources availability (Cavalheiro et al. 2002).

According to Hutson et al. (2001), the deforestation process, caused by agriculture, cattle-breeding and mining is the largest threat to the bats in Neotropical region. Vegetal diversity, size of forest remnants and quality of the area are important for the distribution and abundance of bats (Reis et al. 2000).

Bats provide an interesting opportunity for studies due to their great diversity, wide distribution and flight capacity, being able to move between forest fragments and explore habitats in a complex way (Marini-Filho \& Martins 2000), beyond being good indicators of environmental quality (Medellín et al. 2000). In addition, they are extremely important for forest maintenance due to their roles in seed dispersal and the effects on the consequent regeneration of degraded environments (Miretzki 2003, Bianconi et al. 2006).

About $25 \%$ of known mammals species in Brazil are bats, comprising 167 described species, with 60 species reported for Paraná State (Peracchi et al. 2006, Reis et al. 2008). According to Reis et al. (2008), 27 species of Phyllostomidae, 15 species of Vespertilionidae, 15 species of Molossidae, 2 species of Noctilionidae and 1 species of Emballonuridae were reported in the State. A recent report added Nyctinomops aurispinosus Peale, 1848, increasing the total to 61 species (Bianconi et al. 2008).

Data about the effects of habitat fragmentation on bat fauna diversity and community structure in Brazil are scarce, both in micro and macro-regional level (Pedro 1998). Researches focusing the patterns of relative abundance in continuous forests and in human-modified areas compound the first step to understand the potential of the conservation of fragmented landscapes and their dynamics (Schulze et al. 2000).

Studies reporting the species richness and fauna of chiropterans in forest fragments were undertaken in the Paraná State by Reis \& Muller (1995), Reis et al. (1998, 1999, 2000, 2003, 2006a) and Filho \& Reis (2009). 
In this way, the present study analyzed the species richness and abundance of bat species, captured using mist nets at ground level, during one year, in a forest fragment and in a neighboring reforested area in Rancho Alegre County, Paraná State, Brazil.

\section{MATERIALS AND METHODS}

Study area: The study was undertaken in Fazenda Congonhas, Rancho Alegre County, Paraná State, Southern Brazil (2302'19' S-50'56'04" W), located at 336-340 meters above sea level. It presents a Cfa-type climate, subtropical humid (Köppen 1948), defined as warm, with dry winters and uncommon frosts. The forest region of the Fazenda Congonhas includes a remnant native area and a reforested area, besides the existence of small shrubby areas, Eucalyptus sp. plantation and other reforestations.

Native area (107.8ha) comprises stational semidecidual sub-mountain vegetation with species such as guaxupita (Esenbeckia febrifuga), pau-d'alho (Gallesia integrifolia), pau-jacaré (Piptadenia gonoacantha), alecrim (Holocalyx balansae), peroba-rosa (Aspidosperma polyneuron) (Torezan 2002). The area is surrounded by cultivation of corn, soy and wheat. A selective timber extraction occurred about twenty years ago despite the fact that it is a legal reserve area of the Fazenda Congonhas. Eutrophic red latisol (eutrophic nitosoil) is predominant (Torezan 2002).

The reforestation (11.8ha) was implanted in 2002, by the Laboratory of Biodiversity and Ecosystem Restoration (LABRE) of the State University of Londrina, and included native species of the seasonal forest: mutambo (Guazuma ulmifolia, Sterculiaceae), aroeirinha (Schinus terebinthifolius, Anarcadiaceae), jangadeiro (Heliocarpus americanus, Tiliaceae), embaúba branca or embaúba do brejo (Cecropia pachystachya, Cecropiaceae), crindiúva (Trema micrantha, Ulmaceae) and 20 other species. This patch is adjacent to the native area and the Tibagi River.
Samplings: Four monthly samplings were performed between April 2007 and March 2008, with the April-May-June 2007 months representing the autumn; July-August-September 2007, winter; October-November-December 2007, summer and January-February-March 2008, the spring. The samplings started at nightfall and lasted 6 hours, with two consecutive nights in each sampling station.

Bats were captured with eight mist nets: 20m (1), 12m (2), 10m (4) and 8m (1) in length by $2.5 \mathrm{~m}$ of height, totaling $230 \mathrm{~m}^{2}$ of net per night. The capture effort was the same in each area, totaling $2.76 .10^{3} \mathrm{~h} / \mathrm{m}^{2}$ (Straube \& Bianconi 2002).

The capture technique was based on Greenhall \& Paradiso (1968), with some modifications. Nets were set in the interior of the sampling stations, between $0.5-2.5 \mathrm{~m}$ above the ground and inspected every 15 minutes (Magnini \& Nicola 2006). The samplings were not carried out during the nights with intense rainfall (Esbérard 2007).

After the capture, the measure of the forearm was taken to assist the species identification, according to literature. Two specimens of each species were euthanized and fixed in formaldehyde $10 \%$; afterwards, they were preserved in alcohol $70 \%$ for later confirmation. All other bats were released. Collected animals were deposited in the Zoological Museum of the State University of Londrina (MZUEL).

Data analysis was performed employing the following indices: absolute species richness (S); relative abundance of species (A) and Shannon-Wiener diversity (H') (Magurran 1988), using the PAST software version 1.12 (Hammer et al. 2001). We used a t-test to evaluate the statistical significance of differences between the sampling sites.

A species accumulation curve (collector curve) was built to visualize the accumulation of different collected species, in proportion to the sampling effort (Santos 2006). This type of graphical analysis illustrates the accumulation of different collected species in relation to the increase in sampling effort. According to Santos (2006), these curves represent a suitable 
procedure to evaluate how much an inventory approaches to the capture of the totality of the species in the studied location.

Chao I Index was also applied to estimate expected species richness in both environments using SPADE Software (Species Prediction and Diversity Estimation) (Chao \& Shen 2003). The estimate of richness from Chao I Index is equal to the observed richness, added to the square of the number of species (represented by only one individual in the samples "singletons", divided by the double of the number of species with only two individuals "doubletons" (Santos 2006).

\section{RESULTS}

In total, we captured 502 bats, representing 14 different species, 10 genera and 2 families (Phyllostomidae and Vespertilionidae). All 14 species were captured in the native area and only 6 in the reforested one. We captured 397 and 105 individuals in the native and in the reforested areas, respectively (Table 1).

Phyllostomidae family was the most dominant representing $99 \%$ from the captures. Vespertilionidae represented only $1 \%$ of all bats captured. Individuals from four Phyllostomidae sub-families were collected, with

TABLE 1

Richness and abundance of bat species recorded in Fazenda Congonhas, Rancho Alegre City, Paraná State, Brazil

\begin{tabular}{|c|c|c|c|c|}
\hline $\begin{array}{c}\text { Family } \\
\text { Sub-family }\end{array}$ & Species & $\mathrm{N}^{1}(\%)$ & $\mathrm{R}^{2}(\%)$ & Total \\
\hline \multicolumn{5}{|l|}{ Phyllostomidae } \\
\hline \multicolumn{5}{|l|}{ Phyllostominae } \\
\hline & Micronycteris megalotis Gray, 1842 & $2(0.50)$ & - & 2 \\
\hline & Chrotopterus auritus (Peters, 1856) & $1(0.25)$ & $3(2.86)$ & 4 \\
\hline & Phyllostomus hastatus (Pallas, 1767) & $5(1.26)$ & - & 5 \\
\hline & Phyllostomus discolor Wagner, 1843 & $4(1.00)$ & - & 4 \\
\hline \multicolumn{5}{|l|}{ Stenodermatinae } \\
\hline & Artibeus fimbriatus Gray, 1838 & $36(9.07)$ & $8(7.62)$ & 44 \\
\hline & Artibeus jamaicensis Leach, 1821 & $28(7.05)$ & $2(1.90)$ & 30 \\
\hline & Artibeus lituratus (Olfers, 1818) & $238(59.95)$ & $90(85.71)$ & 328 \\
\hline & Platyrrhinus lineatus (E. Geoffroy, 1810) & $15(3.78)$ & $1(0.95)$ & 16 \\
\hline & Sturnira lilium (E. Geoffroy, 1810) & $25(6.30)$ & - & 25 \\
\hline \multicolumn{5}{|l|}{ Desmodontinae } \\
\hline & Desmodus rotundus (E. Geoffroy, 1810) & $9(2.27)$ & $1(0.95)$ & 10 \\
\hline \multicolumn{5}{|l|}{ Carolliinae } \\
\hline & Carollia perspicillata (Linnaeus, 1758) & $29(7.30)$ & - & 29 \\
\hline \multicolumn{5}{|l|}{ Vespertilionidae } \\
\hline & Lasiurus blossevillii (Lesson \& Garnot, 1826) & $1(0.25)$ & - & 1 \\
\hline & Myotis nigricans (Schinz, 1821) & $1(0.25)$ & - & 1 \\
\hline & Myotis levis (I. Geoffroy , 1824 ) & $3(0.76)$ & - & 3 \\
\hline \multirow{2}{*}{ Total } & Number of individuals & $397(100.00)$ & $105(100.00)$ & 502 \\
\hline & Number of species & 14 & 6 & 14 \\
\hline
\end{tabular}


highest frequency of captures recorded for Stenodermatinae $(89.13 \%)$, followed by Carollinae (5.83\%), Phyllostominae (3.02\%) and Desmodontinae (2.01\%). Artibeus lituratus (Olfers, 1818) was the most common species in both habitats, representing $65.34 \%$ of individuals collected in both fragments.

Artibeus fimbriatus (Gray, 1838) was the second most captured species in the native area, followed by Carollia perspicillata (Linnaeus, 1758), both representing $16.37 \%$ of captures in the forest remnant (Table 1). Artibeus jamaicensis (Leach, 1821), Sturnira lilium (E. Geoffroy, 1810), Platyrrhinus lineatus (Olfers, 1818), Desmodus rotundus (E. Geoffroy, 1810), Phyllostomus hastatus (Pallas, 1767), Phyllostomus discolor (Wagner, 1843), Мyotis levis (I. Geoffroy, 1824), Micronycteris megalotis (Gray, 1842), Chrotopterus auritus (Peters, 1856), Myotis nigricans (Schinz, 1821) and Lasiurus blossevillii (Lesson \& Garnot, 1826) were also verified in the native area, totaling $23.67 \%$.

Besides A. lituratus, specimens of A. fimbriatus, A. jamaicensis, $C$. auritus, $P$. lineatus and $D$. rotundus were also captured in the reforested area (Table 1). The second most abundant species in this environment was $C$. auritus, a carnivorous bat. Individuals from Vespertilionidae family were not recorded in this area.

The Shannon-Wiener Index revealed a significantly greater diversity in the native area $\left(\mathrm{H}^{\prime}=1.4802\right)$ than in the reforested one $\left(\mathrm{H}^{\prime}=0.57015\right)(\mathrm{t}-\mathrm{test}=7.1075, \mathrm{p}<0.05)$. Chao 1 index indicated that the number of estimated species (within the methodology used), with 95\% reliability, amounted to 18 species for the native area $(\mathrm{SE}=2.6, \mathrm{CI}=14.1-29.1)$. This result suggests that our sampling effort recorded approximately $78 \%$ of the total species richness. On the other hand, Chao I estimated 8 species for the reforested area $(\mathrm{SE}=3.7$, $\mathrm{CI}=6.2-28.1$ ), indicating that the sampling in this habitat reported $75 \%$ of total richness.

A higher species accumulation in the first samplings occurred during April, May and June 2007. Nine species, representing $64.3 \%$ of total captures in the forest remnant, were reported during this period in the native area. Approximately $71 \%$ from the total number of species had been reported by the end of the first study period (September). The number increased to 14 species during the following months (Fig. 1).

Sampling in the first three months in the reforested area represented $66.7 \%$ of total captures in this environment. During the first half of the study period (April to September 2007) $83.4 \%$ of species were captured and the number of species remained constant until December. A species was added at the end of sampling, with a total of six species found in the reforested area (Fig. 1).

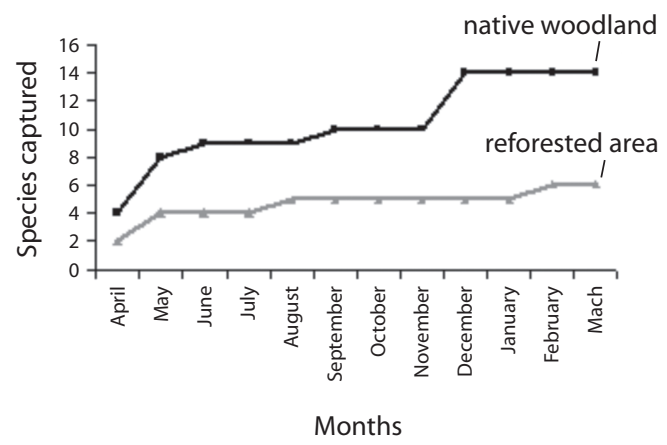

Fig. 1. Total accumulation curve of bat species collected in the Fazenda Congonhas, Paraná, Brazil.

\section{DISCUSSION}

The Phyllostomidae family was dominant regarding the number of individuals and species in the present study. This can be explained by the fact that $90(53.89 \%)$ from the total of 167 species found in Brazil (Reis et al. 2007) belong to this family (Wilson \& Reeder 2005). This is corroborated by the fact that the 27 Phyllostomidae species found in the Paraná State represent the half of all bat species in the State (61 species), according to Reis et al. (2008) and Bianconi et al. (2008). Moreover, the family dominance may be related to the 
method used: nets assembled at 0.5 and $3 \mathrm{~m}$ above the ground, i.e., at the height of most fruit trees that compound the food resource for these animals (Sipinski \& Reis 1995, Pedro 1998). In general, Phyllostomids are frugivorous and do not present a great ability to detect nets (Sekiama 2003).

Species of insectivorous families, such as the Molossids, are not frequently captured in nets at ground level since they typically forage for food above the canopy (Sekiama 2003). They are commonly observed above the canopy and have previously been captured in regions next to the analyzed area (Reis et al. 2002, 2006a, Miretzki 2003). Individuals from the Vespertilionidae family frequently use echolocation system to feed. They can easily detect nets (Handley 1967) and this may explain the low number of captures of these bats in the present study.

In areas of primary forest, a higher number of species was found in other studies (Reis et al. 2000, 2006a). Consequently the diversity values (Shannon-Wiener index) from the present study were also inferior to those observed in other surveys carried out in forest fragments from Paraná State; for instance the study made by Reis et al. (2000) that found $\mathrm{H}^{\prime}=1.66$ in the lower Tibagi area (Fazenda Doralice). However, the value found in the native area is similar to that found in a previous study performed in the middle Tibagi area (Klabin Biological Reserve), where the diversity was $\mathrm{H}^{\prime}=1.58$. Our results evidence the occurrence of a single dominant species. According to Odum (1988), a relatively low percentage is dominant within the total number of species in a community -represented by several specimens- and a high percentage is "rare" (scarcely sampled), with few specimens. This pattern is characteristic of the tropics with defined rainy and dry seasons.

A greater variety of resources and, consequently, a higher number of niches are available to be exploited in areas with upper plant heterogeneity, as in native areas (Pianka 1982, Townsend et al. 2006). Samplings were undertaken in a pre-existing trail bordered by secondary vegetation (including Piperaceae and
Myrtaceae). This vegetation tends to attract frugivorous bats (A. lituratus, A. fimbriatus, A. jamaicensis, C. perspicillata, S. lilium, P. lineatus) which spread seeds and thus contribute for the succession of these communities (Van Der Pijl 1957, Galindo-González et al. 2000, Muscarella \& Fleming 2007). This fact can also explain the greater number of frugivorous recorded in this site.

Less than the half of the species captured in the native area (14) was found in the reforested area (6), and these species were the most common (presented greater relative abundance). This result may be associated to the habitat age (only five years) and size (ten times smaller than the area of native forest). Moreover, it is a very narrow fragment, influenced by edge effects, such as an increase in temperature, solar radiation and direct exposure to winds (Murcia 1995). The area presents a lower number of niches and less variety of habitats, being a more homogeneous environment. In fact, it is composed of vegetation characterized by the initial stages of succession, with a lower availability of resources.

Species richness may be associated to the fragment size (Estrada \& Coates-Estrada 2001). According to Ricklefs (1993), more species occur in larger areas than in smaller ones. This fact may be verified in forest fragments with different sizes in the northern region of Paraná State. For example Mata dos Godoy State Park (680ha), in Londrina County, presents 42 bat species (Reis et al. 2008). On the other hand, only 14 species were found in Fazenda Congonhas (107.8ha). Plant diversity and area quality, besides forest size, are important factors influencing the distribution and abundance of organisms (Reis et al. 2000). A small area with better quality resources may be a better habitat for a greater number of species than a larger area and may influence significantly the species richness (Tamsitt 1967, Zimmerman \& Bierregaard 1986). Besides that, in the Northern region of Paraná State, larger forest fragments are also those with the greatest availability of food resource and shelter (Reis et al. 
2003) accordingly these environments support a greater richness of bat species.

The dominance of A. lituratus in both environments may be explained by its higher ability to survive in modified environments than the other species. A comparable rate of captures of A. lituratus has also been reported in other studies in the Northern region of the Paraná State (Reis \& Muller 1995, Sekiama 2003, Zanon \& Reis 2007).

The presence of $C$. perspicillata, S. lilium and $P$. lineatus in disturbed areas may be related to the capacity to exploit several vegetal strata, taking advantage from the diverse opportunities in environments highly impacted by human activity (Estrada \& Coates-Estrada 2002). Some authors state that these species are indicative of disturbed areas (Medellín et al. 2000, Reis et al.2003). According to Aguiar (1994), the abundance of $C$. perspicillata may decrease in degraded habitats since it is closely related to food preferences (mainly Piperaceae, followed by Solanaceae and Moraceae, respectively) (Uieda \& Vasconcellos-Neto 1985, Muller \& Reis 1992, Mello et al. 2004). This may explain the absence of $C$. perspicillata and $S$. lilium in the reforested area where there is no occurrence of vegetation from the Piperacea family, the main food resource for Carollia and Solanacea family, main resource for Sturnira (Lima \& Reis 2004, Mello 2007).

The capture of the hematophagous Desmodus rotundus may be explained by the presence of cattle-breeding farms close to the study area. This species uses the forests as shelter and stepping stones for the pastureland where they find its food resource (Estrada \& Coates-Estrada 2002). The low percentage reported may be the effect of frequent campaigns of rabies prevention undertaken for the population control of hematophagous bats (Bredt et al. 1996), even though these have not occurred in the area.

The occurrence of $C$. auritus is more related with the food availability (Lazo 2004). The low percentage is due to the carnivorous diet, since this species is a top predator in the food chain. Furthermore, these predators are large animals feeding on large preys, therefore they need an extensive territory to exploit and survive. Micronycteris megalotis is considered a more sensitive species, only found in well preserved areas (Medellín et al. 2000), being restricted to the continuous forests or less disturbed areas (Fenton et al. 1992, Reis \& Muller 1995, Cosson et al. 1999, Schulze et al. 2000, Stoner \& Lobo 2002, Gorresen \& Willig 2004). This pattern may be found mainly in the Phyllostominae sub-family, which is more sensitive to environmental degradation and may be an indicator of degraded areas (Fenton et al. 1992, Medellín et al. 2000, Falcão et al. 2003). The omnivorous species $P$. hastatus and $P$. discolor (1\%), with a varied diet, are also found in highly altered environments (Nogueira et al. 2007).

A higher number of bats were registered during the dry season (April to September), although other studies verified greater abundance of frugivorous (including A. lituratus and A. fimbriatus) during the rainy season (Pedro \& Taddei 2002, Falcão et al. 2003, Aguiar \& Marinho-Filho 2004). Several individuals were observed feeding on the fruits of Ficus $\mathrm{sp}$ during the dry season. Due to its intraspecific asynchronic pattern of fructification with fruits (Figs. 1 and 2) that are produced throughout the whole year (Pereira et al. 2007), the Ficus native area may have provided food to the bats during the period with low availability of food, resulting in more captures of individuals during the dry period. According to Terborgh (1986), some vegetal species are "key resources" for frugivorous animals.

Esbérard (2007) points that the capture efficiency decreases gradually when the samplings are undertaken during non-consecutive nights (intervals of approximately 29 days), without any change in net positions. Fact possibly associated to the learning of the bats (Simmons \& Voss 1998), which memorize the nets positions and avoid flying where they had been assembled or use frequently the echolocation, being able to deviate from the nets and fly to other areas.

The total number of species was higher in the spring-October to December- (Fig. 2) 


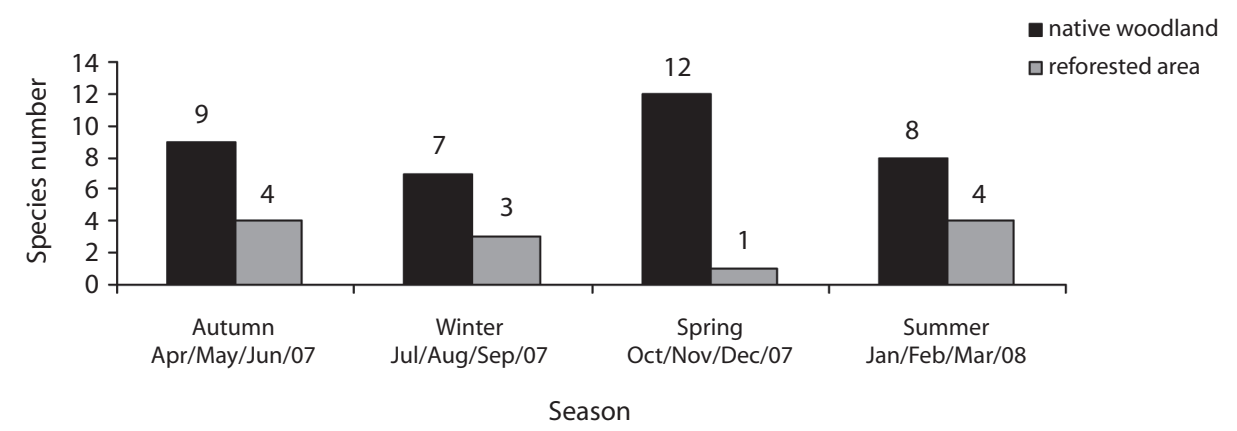

Fig. 2. Number of species captured during the different seasons in the Fazenda Congonhas, Paraná, Brazil.

influenced by an increase in food resources (Fleming et al. 1972), including fruits and insects. In fact, insectivorous bats (Myotis levis, Myotis nigricans and Lasiurus blossevillii) were found only during this period. Pedro et al. (2001) observed that, in the case of insectivorous bats, there is a direct relationship between the number of species and the size of the forest fragment. This fact may explain the capture of these species only in the native area.

According to Townsend et al. (2006), the most frequent captured species may be found in the first samplings and the non-frequent ones, which may also be rarer, are added to the list according to the increase in the number of samplings. In the context of capture effort, Chao 1 Index pointed out that there may be 18 species in the native area and 8 species in the reforested one, with greater number of samplings and periods.

Native areas provide habitat for a more diverse community of bats by furnishing a greater variety of habitats. Meanwhile, the reforestation is essential since it decreases the edge effects and prevents radical changes in the micro-climate within the neighboring areas of the fragment. The species without such protection may be more susceptible to predators (Reis et al. 2006b). Reforestation, as a continuity of the forest remnant, benefits opportunist and generalist species in their occupation of new available niches surrounding the forest. It also decreases the loss of shelter contributing for the survival of bat species, and to a possible increase of the area for these species, as well as an increase of the population; therefore reducing the possible endocrossing in these areas.

The strategies for bat conservation should consider that these animals exploit a set of food sources (fruits, insects, small vertebrates, etc.) and roosting structures for protection (crevices in rocks, cracks in trees and even under leaves). Besides preserving specific environments, it is also necessary to preserve other types of habitats used as food resources or as flight routes to avoid possible predators. Furthermore, the reforestation around native areas is essential since they play the role of matrix environment which sustains some species found in the original primary forest. Conservation and implementation of management plans in forest remnants is highly important to lessen the deleterious effects caused by the destruction and modification of natural environments.

\section{ACKNOWLEDGMENTS}

We would like to thank the Post-graduate Program from the State University of Londrina; LABRE for technical and logistic support; the administration of the Fazenda Congonhas that allowed the accomplishment of this study; Ed for his inestimable help in field work; to everyone that contributed with this research: Isaac, Cibele, Renata, Cássius; Carolina Cheida and 
Gisele Doratti, for reviewing the manuscript; CAPES for funding research.

\section{RESUMEN}

Por lo general, los entornos naturales se han transformado en pequeños remanentes de bosque, con la consecuente pérdida de hábitat y la extinción de especies. El Norte del Estado de Paraná no es una excepción, ya que sólo 2 a $4 \%$ del ecosistema original se presenta en pequeños fragmentos de bosque estacional semideciduo. En este estudio observamos la riqueza de especies y abundancia de murciélagos en dos fragmentos de bosque de Fazenda Congonhas, en Rancho Alegre, de Paraná, Brasil. Se realizaron cuatro muestreos en cada área, una nativa legalmente protegida (107.8ha) y una reforestada (11.8ha) entre abril 2007 y marzo 2008. Al caer la noche en cada sitio se colocaron ocho redes de niebla por seis horas durante dos noches consecutivas. Se capturaron 397 individuos, 14 especies y 10 géneros en la zona nativa y 105 individuos, seis especies y cuatro géneros en la reforestada. Artibeus lituratus fue la especie más común en ambos fragmentos $(\mathrm{n}=328,65.3 \%)$, seguido por Artibeus fimbriatus $(\mathrm{n}=44$, $8.8 \%)$ y Artibeus jamaicensis $(\mathrm{n}=30,6.0 \%)$. Otras especies incluyendo Platyrrhinus lineatus, Carollia perspicillata, Sturnira lilium, Chrotopterus auritus, Desmodus rotundus, Michronycteris megalotis, Phyllostomus hastatus, Phyllostomus discolor, Myoti levis, Myotis nigricans and Lasiurus blossevillii, constituyeron el $19.9 \%$ de las capturas. El área nativa presentó mayores valores de riqueza de especies $(\mathrm{S}=14)$ y diversidad $\left(\mathrm{H}^{\prime}=1.4802\right)$ en comparación con la reforestada $\left(\mathrm{S}=6, \mathrm{H}^{\prime}=0.57015\right)$. El t-test evidenció una diferencia significativa en la diversidad de los sitios $(\mathrm{t}=7.1075)$. El índice Chao 1 indicó que el esfuerzo de muestreo registró el $78 \%$ de la riqueza total de especies en la zona nativa y $75 \%$ en la reforestada. Por lo tanto, la preservación del fragmento de bosque es esencial, ya que proporciona un hábitat para una diversa comunidad de murciélagos. Las acciones de manejo forestal y la reforestación pueden evitar cambios drásticos en el microclima de las áreas vecinas al fragmento de bosque y podría permitir la ocupación de nichos disponibles en la zona, por especies generalistas y oportunistas.

Palabras Clave: Quirópteros, fragmentos de bosque, diversidad, conservación, bosque del Atlántico.

\section{REFERENCES}

Aguiar, L.M.S. 1994. Comunidades de Chiroptera em três áreas de Mata Atlântica em diferentes estágios de sucessão, Estação Biológica de Caratinga, Minas gerais. Master Thesis, Minas Gerais State University, Belo Horizonte, Minas Gerais, Brazil.
Aguiar, L.M.S. \& J. Marinho-Filho. 2004. Activity patterns of nine phyllostomid bat species in a fragment of the Atlantic Forest in southeastern Brazil. Rev. Bras. Zool. 21: 385-390.

Bianconi, G.V., S.B. Mikich \& W.A. Pedro. 2006. Movement of bats (Mammalia, Chiroptera) in Atlantic Forest remnants in southern Brazil. Rev. Bras. Zool. 23: 1199-1206.

Bianconi, G.V., U.M.S. Suckow, D.C. Carneiro, L.C. Parolin \& R. Gregorin. 2008. Primeiro registro de Eumops perotis e Nyctinomops aurispinosus para o estado do Paraná, sul do Brasil. Abstracts-IV Brazilian Mammalogical Congress, São Lourenço, Minas Gerais, Brazil.

Bredt, A.I., F.A.A. Araújo, J. Caetano-Júnior, M.G.R. Rodrigues, M. Yoshizawa, M. M.S. Silva, N.M.S. Harmani, P.N.T. Massunaga, S.P. Burer, V.A.R. Potro \& W. Uieda. 1996. Morcegos em áreas urbanas e rurais: manual de manejo e controle. Fundação Nacional de Saúde, Ministério da Saúde, Brazil.

Cavalheiro, A.L., J.M.D. Torezan \& E.L. Fadelli. 2002. Recuperação de áreas degradadas: procurando por diversidade e funcionamento dos ecossistemas, p. 213-224. In M.E. Medrim, E. Bianchini, O.A. Shibatta \& J.A. Pimenta (eds.). A bacia do rio Tibagi. Londrina, Paraná, Brazil.

Chao, A. \& T.J. Shen. 2003. Program SPADE (Species Prediction and Diversity Estimation). (Downloaded: August 10, 2007, www.chao.stat.nthu.edu.tw).

Cosson, J.F., J.M. Pons \& D. Masson. 1999. Effects of forest fragmentation on frugivorous and nectarivorous bats in French Guiana. J. Trop. Ecol. 15: 515-534.

Cusack, D. \& F. Montagnini. 2004. The role of native species plantations in recovery of understory woody diversity in degraded pasturelands of Costa Rica. Forest Ecol. Manag. 188: 1-15.

Esbérard, C.E.L. 2007. Influência do ciclo lunar na captura de morcegos Phyllostomidae. Iheringia Ser. Zool. 97: 81-85.

Estrada, A. \& R. Coates-Estrada. 2001. Bat species richness in live and in corridors of residual rain forest vegetation at los Tuxtlas, Mexico. Ecography 24: 94-102.

Estrada, A. \& R. Coates-Estrada. 2002. Bats in continuous forest, forest fragments and in a agricultural mosaic habitat-island at Los Tuxtlas, Mexico. Biol. Conserv. 103: $237-245$. 
Falcão, F.C., V.F. Rebêlo \& S.A. Talamoni. 2003. Structure of a bat assemblage (Mammalia, Chiroptera) in Serra do Caraça Reserve, South-east Brazil. Rev. Bras. Zool. 20: 347-350.

Fenton, M.B., L. Acharya, D. Audet, M.B.C. Hickey, C. Merriman, M.K. Obrist, D.M. Syme \& B. Adkins. 1992. Phyllostomid Bats (Chiroptera: Phyllostomidae) as indicators of habitat disruption in the Neotropics. Biotropica 24: 440-446.

Filho, H.O. \& N.R. Reis. 2009. Species richness and abundance of bats in fragments of the stational semidecidual forest, Upper Paraná River, southern Brazil. Braz. J. Biol. 69: 727-734.

Fleming, T.H., E.T. Hooper \& D.E. Wilson. 1972. Three Central American bats communities: structure, reproductive cycles, and movement patterns. Ecology 53: 555-569.

Galindo-González, J., S. Guevara \& V.J. Sosa. 2000. Batand Bird- Generated Seed Rains at Isolated Trees in Pastures in a Tropical Rainforest. Conserv. Biol. 85: 1693-1703.

Gorresen, P.M. \& M. Willig. 2004. Landscape Responses of Bats to Habitat Fragmentation in Atlantic Forest of Paraguay. J. Mammal. 85: 688-687.

Greenhall, A.M. \& J.L. Paradiso. 1968. Bats and bat banding. Bureau of Sport Fisheries and Wildllife Resource Publication 72: 1-47.

Hammer, Ø., D.A.T. Harper \& P.D. Ryan. 2001. PASTPalaeontological Statistics.

Handley Jr., C.O. 1967. Bats of the canopy of an Amazonian Forest. Actas of the symposium on the Amazonian Biota (Zoology) 5: 211-215.

Hero, J.M. \& T. Ridgway. 2006. Declínio Global de Espécies, p. 53-90. In C.F.D. Rocha, H.G. Bergallo, M.V. Sluys \& M.A.S. Alves (eds.). Biologia da Conservação: Essências. São Carlos, São Paulo, Brazil.

Holl, K.D., M.E. Loik, E.H.V. Lin \& I.A. Samuels. 2000. Tropical montane forest restoration in Costa Rica: overcoming barriers to dispersal and establishment. Restor. Ecol. 8: 339-349.

Hutson, A.M., S.P. Mickleburgh \& P.A. Racey. 2001 Microchiropteran bats: global status survey and conservation action plan. IUCN/SSC Chiroptera Specialist Group. IUCN Gland, Switzerland and Cambridge, England.

Köppen, W. 1948. Climatologia. Fondo de Cultura Económica, Mexico City, Mexico.
Lazo, L.J. 2004. A mastofauna da Fazenda Figueira em uma área do Baixo Tibagi, Município de Londrina, Paraná. Master Thesis, São Paulo University, Piracicaba, São Paulo, Brazil

Lima, I.P. \& N.R. Reis. 2004. The availability of piperaceae and the search for this resource by Carollia perspicillata (Linnaeus) (Chiroptera, Phyllostomidae, Carollinae) in Parque Municipal Arthur Thomas, Londrina, Paraná, Brazil. Rev. Bras. Zool. 21: 371377 .

Magnini, P.R. \& P.A. Nicola. 2006. Captura e marcação de animais silvestres, p. 91-151. In L. Cullen Jr., R. Rudran \& C. Valladares-Padua (eds.). Métodos de estudos em biologia da conservação \& manejo da vida silvestre. Curitiba, Paraná, Brazil.

Magurran, A.E. 1988. Ecological diversity and its measurement. Cambridge University, London, England.

Marini-Filho, O.J. \& R.P. Martins. 2000. Teoria de metapopulações. Novos princípios na biologia da conservação. Ciência Hoje 27: 23-29.

Medellín, R.A., M. Equiiiua \& M.A. Amin. 2000. Bat diversity and abundance as indicators of disturbance in neotropical rainforests. Conserv. Biol. 14: 1666167.

Mello, M.A.R. 2007. Interações entre o morcego Sturnira lilium (Chiroptera: Phyllostomidae) e plantas da família Solanaceae. Biota Neotropica. (Downloaded: September 05, 2008, http://www.biotaneotropica.org. br/v7n1/es/fullpaper? bn02807012007+pt).

Mello, M.A.R., G.M. Schittini, P. Selig \& H.G. Bergallo. 2004. A test of climate and fruiting of Piper species (Piperaceae) on reproductive patterns of the bat Carollia perspicillata (Phyllostomidae). Acta Chiropterol. 6: 309-318.

Miretzki, M. 2003. Morcegos do estado do Paraná, Brasil (Mammalia, Chiroptera): riqueza de espécies, distribuição e síntese do conhecimento atual. Papéis Avulsos de Zoologia 43: 101-138.

Muller, M.F. \& N.R. Reis. 1992. Partição de recursos alimentares entre quatro espécies de morcegos frugívoros (Chiroptera, Phyllostomidae). Rev. Bras. Zool. 9: $345-355$

Murcia, C. 1995. Edge effects in fragmented forests: implications for conservation. Tree 10: 58-62.

Muscarella, R. \& T.H. Fleming. 2007. The role of frugivorous bats in tropical forest succession. Biol. Rev. 82: $573-590$ 
Nogueira, M.R., A.L. Peracchi \& R. Moratelli. 2007. Subfamília Phyllostominae, p. 61-97. In N.R. Reis, A.L. Peracchi, W.A. Pedro \& I.P. Lima (eds.). Morcegos do Brasil. Londrina, Paraná, Brazil.

Odum, E.P. 1988. Ecologia. Thomson, Rio de Janeiro, Rio de Janeiro, Brazil.

Pedro, W.A. 1998. Diversidade de morcegos em habitats florestais fragmentados do Brasil (Chiroptera, Mammalia). Ph.D. Thesis, Federal University São Carlos, São Carlos, São Paulo, Brazil.

Pedro, W.A., F. Passos \& B.K. Lim. 2001. Morcegos (Chiroptera; Mammalia) da Estação Ecológica dos Caetetus, estado de São Paulo. Chiroptera Neotropical 7: 136-140.

Pedro, W.A. \& V.A. Taddei. 2002. Temporal distribution of five bats species (Chiroptera, Phyllostomidae) from Panga Reserve, south-eastern Brazil. Rev. Bras. Zool. 19: 951-954.

Peracchi, A.L., I.P. Lima, N.R. Reis, M.R. Nogueira \& H. Ortêncio-Filho. 2006. Ordem Chiroptera, p. 153230. In N.R. Reis, A.L. Peracchi, W.A. Pedro \& I.P. Lima (eds.). Mamíferos do Brasil. Londrina, Paraná, Brazil.

Pereira, R.A.S., E. Rodrigues \& A.O. Menezes Jr. 2007. Phenological patterns of Ficus citrifolia (Moraceae) in a seasonal humid-subtropical region in Southern Brazil. Plant Ecol. 188: 265-275.

Pianka, E.R. 1982. Ecologia evolutiva. Omega, Barcelona, Spain.

Pires, A.S., F.A.S. Fernandez \& C.S. Barros. 2006. Vivendo em um Mundo em Pedaços: Efeitos da fragmentação Florestal sobre Comunidades e Populações Animais, p. 231-260. In C.F.D. Rocha, H.G. Bergallo, M.V. Sluys \& M.A.S. Alves (eds.). Biologia da Conservação: Essências. São Carlos, São Paulo, Brazil.

Reis, N.R. \& M.F. Muller. 1995. Bat diversity of forests and open areas in a subtropical region of south Brazil. Ecologia Austral. 5: 31-36.

Reis, N.R., A.L. Peracchi, I.P. Lima, M.L. Sekiama \& V.J. Rocha. 1998. Updated list of the chiropterians of the city of Londrina, Paraná, Brazil. Chiroptera Neotropical 4: 96-98

Reis, N.R., A.L. Peracchi \& M.L. Sekiama. 1999. Morcegos da Fazenda Monte Alegre, Telêmaco Borba, Paraná (Mammalia, Chiroptera). Rev. Bras. Zool. 16: 501-505.
Reis, N.R., A.L. Peracchi, M.L. Sekiama \& I.P. Lima. 2000. Diversidade de morcegos (Chiroptera, Mammalia) em fragmentos florestais do estado do Paraná, Brasil. Rev. Bras. Zool. 17: 697-704.

Reis, N.R., A.L. Peracchi \& I.P. Lima. 2002. Morcegos da bacia do rio Tibagi, p. 251-270. In M.E. Medri, E. Bianchini, O.A. Shibatta \& J.A. Pimenta (eds.). A bacia do rio Tibagi. Londrina, Paraná, Brazil.

Reis, N.R., M.L.S. Barbieri, I.P. Lima \& A.L. Peracchi. 2003. O que é melhor para manter a riqueza de espécies de morcegos (Mammalia, Chiroptera): um fragmento florestal grande ou vários fragmentos de pequeno tamanho? Rev. Bras. Zool. 20: 225-230.

Reis, N.R., A.L. Peracchi, I.P. Lima \& W.A. Pedro. 2006a. Riqueza de espécie de morcegos (Mammalia, Chiroptera) em dois diferentes habitats, na região centro-sul do Paraná, sul do Brasil. Rev. Bras. Zool. 23: 813-816.

Reis, N.R., I.P. Lima \& A.L. Peracchi. 2006b. Morcegos (Chiroptera) da área urbana de Londrina, Paraná, Brasil. Rev. Bras. Zool. 19: 739-746.

Reis, N.R., O.S. Shibatta, A.L. Peracchi, W.A. Pedro \& I.P. Lima. 2007. Sobre os morcegos brasileiros, p. 17-25. In N.R. Reis, A.L. Peracchi, W.A. Pedro \& I.P. Lima (eds). Morcegos do Brasil. Londrina, Paraná, Brazil.

Reis, N.R., I.P. Lima \& M. Miretzki. 2008. Morcegos do Paraná, p. 143-148. In N.R. Reis, A.L. Peracchi \& G.A.S.D. Santos (eds.). Ecologia de Morcegos. Londrina, Paraná, Brazil.

Ricklefs, R.E. 1993. A Economia da Natureza. Guanabara Koogan, Rio de Janeiro, Rio de Janeiro, Brazil.

Santos, A.J. 2006. Estimativas de riqueza em espécies, p. 19-41. In L. Cullen Jr., R. Pudran \& C. ValladaresPadua (eds.). Métodos de estudos em biologia da conservação \& manejo da vida silvestre. Universidado Federal do Paraná, Curitiba, Paraná, Brazil.

Sekiama, M.L. 2003. Um estudo sobre quirópteros (Chiroptera: Mammalia) abordando ocorrência e capturas, aspectos reprodutivos, dieta e dispersão de sementes no Parque Nacional do Iguaçu, PR, Brasil. Ph.D. Thesis, Federal University Parana, Curitiba, Parana, Brazil.

Schulze, M.D., N.E. Seavy \& D. Witacre. 2000. A comparison of the Phyllostomid bat assemblages in undisturbed neotropical forest and in forest fragments of a slash-and-burn farming mosaic in Petén, Guatemala. Biotropica 32: 174-184. 
Simmons, N.B. \& R.S. Voss. 1998. The mammals of Paracou, French Guiana: a neotropical lowland rainforest fauna part 1. Bats. B. Am. Mus. Nat. Hist. 237: $1-219$.

Sipinski, E.A.B. \& N.R. Reis. 1995. Dados ecológicos dos quirópteros da Reserva Volta Velha, Itapoá, Santa Catarina, Brasil. Rev. Bras. Zool. 12: 519-528.

Stoner, Q. \& R.G. Lobo. 2002. Effects of forest fragmentation on the Colima Long-nosed bat (Musonycteris harrisoni) foraging in tropical dry forest of Jalisco, Mexico. Biotropica 34: 462-467.

Straube, F.C. \& G.V. Bianconi. 2002. Sobre a grandeza e a unidade utilizada para estimar esforço de captura com utilização de redes-de-neblina. Chiroptera Neotropical 8: 150-152.

Tamsitt, J.R. 1967. Niche and species diversity in neotropical bats. Nature 213: 784-786.

Terborgh, J. 1986. Keystone plant resources in the tropical forest, p. 330-344. In M.E Saule (ed.). Conservation biology: the science of scarcity and diversity. Sinauer, Sunderland, Mass., USA.
Torezan, J.M.D. 2002. Nota sobre a vegetação da bacia do rio Tibagi, p. 103-107. In M.E. Medri, E. Bianchini, O.A. Shibatta \& J.A. Pimenta (eds.). A bacia do rio Tibagi. Londrina, Paraná, Brazil.

Townsend, C.R., M. Begon \& J.L. Harper. 2006. Fundamentos em ecologia. Artmed, Porto Alegre, Rio Grande do Sul, Brazil.

Uieda, W. \& J. Vasconcellos-Neto. 1985. Dispersão de Solanum spp. (Solanaceae) por morcegos na região de Manaus, AM, Brasil. Rev. Bras. Zool. 2: 449-458.

Van Der Pijl, L. 1957. The dispersal of plants by bats (Chiropterocory). Acta Bot. Neerl. 6: 291-315.

Wilson, D.E. \& D.M. Reeder. 2005. Mammal species of the world: a taxonomic and geographic reference. Johns Hopkins University,Washington D.C., USA.

Zanon, C.M.V. \& N.R. Reis. 2007. Bats (Mammalia, Chiroptera) in the Ponta Grossa region, Campos Gerais, Parana, Brazil. Rev. Bras. Zool. 24: 327-332.

Zimmerman, B.L. \&. R.O. Bierregaard Jr. 1986. Relevance of the equilibrium theory of island biogeographic with an example from Amazônia. J. Biogeogr. 13: 133-143. 